\title{
Red ceramics produced from mixtures of kaolinite clay and waste glass
}

\author{
Emmanuel Tiffo ${ }^{1}$, Antoine Elimbi ${ }^{1 *}$, Joseph Dika Manga ${ }^{2}$ and Arlin Bruno Tchamba ${ }^{3}$
}

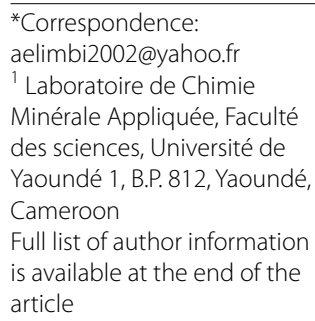

\begin{abstract}
Red ceramics were produced at $750^{\circ} \mathrm{C}$ by mixing reddish yellow kaolinite clay from Marom (West Region of Cameroon) with waste glass (percentage ranging between 0 and $15 \%$ mass). Depending on the nature of the materials, kaolinite clay, waste glass and ceramics were characterized by determination of chemical and mineralogical compositions, linear shrinkage, water absorption, flexural strength and variation of color of fired samples. Thermal analysis and Fourier transform infrared spectroscopy were done as well. The final color of ceramics was red, water absorption varied between 17.40 and 13.70\%, linear shrinkage ranged between 0.70 and $1.20 \%$ and flexural strength was between 5.30 and $8.10 \mathrm{MPa}$. These results showed that mixing kaolinite clay with waste glass is an interesting process to get red ceramics destined for red bricks or roofing tiles at $750^{\circ} \mathrm{C}$.
\end{abstract}

Keywords: Kaolinite clay, Waste glass, Mixtures, Red ceramics

\section{Background}

Since millennia, people have been using clay products in various forms such as earth blocks, fired bricks, roofing tiles for construction and other related uses. These materials are important to our daily life with respect to their properties which enable human beings to construct buildings all around the world according to their mechanical strength, durability, water absorption or chemical resistance (Aubert et al. 2013). SubSaharan Africa countries have potential sources of clay deposits for which kaolinite is generally the main mineral associated among other with quartz, goethite, hematite, anatase and alkaline oxides (Yakoubi et al. 2006; Traoré et al. 2007). These last oxides require low temperature to melt and act as binders which link particles of clay during the sintering process. However clays with low alkaline oxide and great amount of iron oxide require high temperature for maturation so as to get suitable ceramic products (Aliprandi 1979; Sei et al. 2004; Elimbi et al. 2014). It is an appeal to reduce energy consumption and to protect our environment for sustainable development (Oti and Kinuthia 2012; Sultana et al. 2015). The world over, treatment and management of wastes is crucial (Suzuki and Tanaka 1997; Sultana et al. 2015). Studies referring to addition of low quantity of certain types of waste to clays in order to manufacture reliable ceramic products such as fired bricks remain of date (Zhang 2013). Waste glass must receive careful

(c) 2015 Tiffo et al. This article is distributed under the terms of the Creative Commons Attribution 4.0 International License (http:// creativecommons.org/licenses/by/4.0/), which permits unrestricted use, distribution, and reproduction in any medium, provided you give appropriate credit to the original author(s) and the source, provide a link to the Creative Commons license, and indicate if changes were made. 
attention for environmental issues according to their non-biodegradable nature and can be recycling into new items. Waste glass can be utilized as flux to replace common fluxes such as feldspar or other mineral fluxes to save energy in ceramic manufacturing process (Bragança and Bergmann 2004; Rozenstrauha et al. 2006; Raimondo et al. 2007; Rambaldi et al. 2007; Andreola et al. 2008; Dondi et al. 2009; Djangang et al. 2014).

The present study focused on determination of physical characteristics (such as linear shrinkage, water absorption, variation of color) and flexural strength of ceramics obtained at $750^{\circ} \mathrm{C}$ using waste glass and reddish yellow colored kaolinite clay whose composition contains high mass percentage of iron oxide and low mass percentage of alkaline oxides. However, waste glass is abundant and available especially in urban zones as consequence of daily activities. In spite of this, in many African countries and particularly in Cameroon, there is not always specialized industries in charge of collecting, storing and reusing of waste materials, while it can provide added economical benefits if waste glass can be converted to useful materials and be recycled (Rambaldi et al. 2007; Djangang et al. 2014). Hence this can make waste glass potential secondary input for traditional ceramics production. Such formulations are typically used to manufacture building materials such as fired bricks or roofing tiles. Clays are very common raw materials of such products and glass addition is the opportunity to reuse waste glass to lower maturation temperature in order to reduce the cost of production of these ceramic products in economic plan.

\section{Materials and experimental methods Materials}

The studied clay material labeled as $\mathrm{K}$ was collected from the area of Marom (West Region of Cameroon) which is located in the central domain of the PanAfrican belt of Cameroon (Nzenti et al. 1998; Ganwa et al. 2008). This area is composed of gneisses and granites partly capped by volcanic rocks of tertiary age from the "Cameroon Volcanic Line". Geology formations of the Maron area are mainly mylonites of granite compositions and clay minerals that were probably developed thanks to the strong mylonitization of the rocks that facilitated circulations of superficial waters and thus the strong alteration of granitic rocks. Once collected, blocks of reddish yellow colored clay sample were first cured at room temperature for 2 weeks then dried at $105^{\circ} \mathrm{C}$ for $48 \mathrm{~h}$. The dried blocks were crushed and then ground in a ball mill and the resulted powder was sifted using an $80 \mu \mathrm{m}$ mesh sieve. Colorless waste glass bottles collected from garbage cans, were broken into pieces, washed and dried at $105^{\circ} \mathrm{C}$. The resulted pieces were crushed then sieved via an $80 \mu \mathrm{m}$ mesh sieve to get colorless glass powder which was labeled as V.

\section{Experimental methods}

Four types of mixtures denoted as $\mathrm{KV}_{0}, \mathrm{KV}_{1}, \mathrm{KV}_{2}$ and $\mathrm{KV}_{3}$ were elaborated between powders of $\mathrm{K}$ and $\mathrm{V}$ according to mass compositions of Additional file 1: Table S1. To get a mixture, powders of $\mathrm{K}$ and $\mathrm{V}$ were homogenized in distilled water in order to get a slurry which was kept at the ambient atmosphere of the laboratory for $24 \mathrm{~h}$. The mixture was completely oven-dried at $110^{\circ} \mathrm{C}$ for $72 \mathrm{~h}$ then crushed and sieved using an $80 \mu \mathrm{m}$ sieve. For each type of mixture, two kinds of test samples were produced by extrusion: parallelepiped $(82 \mathrm{~mm} \times 42 \mathrm{~mm} \times 9 \mathrm{~mm})$ and cylindrical $(13 \mathrm{~mm}$ diameter and 
$9 \mathrm{~mm}$ height). The obtained test specimens were cured for $48 \mathrm{~h}$ at ambient temperature of laboratory, oven-dried at $110^{\circ} \mathrm{C}$ for $48 \mathrm{~h}$ then fired in a kiln (Nabertherm, model $\mathrm{LH}$ $60 / 40$ ) at $750^{\circ} \mathrm{C}$ at the rate of $5^{\circ} \mathrm{C} / \mathrm{min}$ for two hours. The firing temperature of $750^{\circ} \mathrm{C}$ was chosen as a result of preliminary test which showed that the used glass powder started to melt around $700^{\circ} \mathrm{C}$. The chemical analysis was carried out by Inductive Coupled Plasma-Atomic Emission Spectrometry via a Perkin Elmer-Optima 7000DV device. The crystalline phases were determined by X-ray diffraction using a Philip PW 3050/60 diffractometer which operated by reflection of $\mathrm{K}_{1}$ radiation of Copper. Thermal analysis were performed thanks to a NETZSCH STA-449F3 (TG and DTA) operating at the rate of $20^{\circ} \mathrm{C} / \mathrm{min}$ and an Adamel-Lomargy model DM-15 (dilatometry) which operated at the speed of $5^{\circ} \mathrm{C} / \mathrm{min}$. Fourier transform infrared spectroscopy (FTIR) was performed with the aid of a Bruker Alpha-P, operating in absorbance mode. The variation of color of fired products versus temperature was examined using the Munsell Soil Color Charts (2000). Linear shrinkage was determined on parallelepiped fired test specimens thanks to a caliper (ROCH France, Patented S.G.D.G.) and water absorption was carried out on cylindrical fired test specimens using NF-P-18-554 standard (Norme Française 1979). Flexural strength was performed according to EN-100 standard (Norme Européenne 1982) on parallelepiped fired test specimens using an electro-hydraulic press $(M \mathcal{E} O$, type 11.50, and No 21) operating at an average rate of $3 \mathrm{~mm} / \mathrm{min}$.

\section{Results and discussion}

\section{Raw materials characterization}

\section{Clay sample}

The chemical composition of the $\mathrm{K}$ clay is given in Additional file 2: Table S2. It appears that $\mathrm{SiO}_{2}$ content is $44.70 \%$ mass against $18.50 \%$ mass for $\mathrm{Al}_{2} \mathrm{O}_{3}$. The molar ratio of $\mathrm{SiO}_{2}$ / $\mathrm{Al}_{2} \mathrm{O}_{3}$ is 4.1 against 2 for pure kaolinite which allows to classify the $\mathrm{K}$ clay as a siliceous one (Djangang et al. 2007). The $\mathrm{Fe}_{2} \mathrm{O}_{3}$ mass percentage of 20.10 is high and this is not favorable to allow for ceramics with high mechanical values (Ergul et al. 2007; Bernhardt et al. 2014). Conversely, this amount of $\mathrm{Fe}_{2} \mathrm{O}_{3}$ in presence of uncolored waste glass is beneficial to get red colored ceramics (Karaman et al. 2006; Vieira et al. 2008; Sultana et al. 2015). This is an important technological aspect that renders possible the use of $\mathrm{K}$ clay for the production of ceramics with red tonality, especially for roofing and rustic floor tiles, then worthwhile for the manufacture of terra cotta. Due to the great amount of $\mathrm{Fe}_{2} \mathrm{O}_{3}$ in the $\mathrm{K}$ clay and presence of low content of $\mathrm{Na}_{2} \mathrm{O}+\mathrm{K}_{2} \mathrm{O}(3.30 \%$ mass $)$ and $\mathrm{CaO}(0.51 \%$ mass), oxides which act as fluxes at temperatures greater than $1,000^{\circ} \mathrm{C}$, the sintering of this clay material could require high temperature to get reliable ceramics. Hence using the $\mathrm{K}$ clay for ceramic production might need adjustment of its chemical composition (Sei et al. 2004; Arib et al. 2007; Elimbi et al. 2014; Djangang et al. 2014). This can be possible through addition of energetic fluxing agents such as sodium or potassium feldspars or waste glass (Bragança and Bergmann 2004; Rozenstrauha et al. 2006; Arib et al. 2007; Raimondo et al. 2007; Rambaldi et al. 2007; Andreola et al. 2008; Dondi et al. 2009; Djangang et al. 2014). The little amount of $\mathrm{K}_{2} \mathrm{O}(2.93 \%)$ might suggest the presence of mica mineral (Vieira et al. 2008; Sultana et al. 2015). Also, the presence of $0.64 \%$ mass of $\mathrm{TiO}_{2}$ allows expecting that the $\mathrm{K}$ clay might contain either rutile or anatase. Hence, in addition to the great iron oxide amount, the presence of rutile or anatase will enable to get ceramics with 
red color (Chen et al. 2011; Quijorna et al. 2012; Bernhardt et al. 2014). Loss on ignition is $12.69 \%$ and this is not very far from the values commonly encountered for kaolinite clay rich materials $(14.00 \%)$. In fact, the present result correlates well with the high molar ratio of $\mathrm{SiO}_{2} / \mathrm{Al}_{2} \mathrm{O}_{3}$ (4.10) and the great iron oxide amount (20.10\% mass) which may let to predict the presence of iron oxi-hydroxide minerals in the K clay. The FTIR spectrum of $\mathrm{K}$ is shown in Fig. 1. The absorption bands at 3,694-3,620 $\mathrm{cm}^{-1}$ express the stretching vibrations of $-\mathrm{OH}$ groups of kaolinite network (Kakali et al. 2001; Bich et al. 2009; Hafid and Hajjaji 2015). The bands located at 3,402 and 1,640 $\mathrm{cm}^{-1}$ correspond respectively to stretching vibrations of water molecules while those at 998 and $788 \mathrm{~cm}^{-1}$ express the vibration of $\mathrm{Si}-\mathrm{O}-\mathrm{Al}$ group of the network (Kakali et al. 2001; Bich et al. 2009; Hafid and Hajjaji 2015). The bands at 909 and at $789 \mathrm{~cm}^{-1}$ indicate the stretching vibration of $\mathrm{Al}-\mathrm{OH}$ with $\mathrm{Al}$ in VI coordination (Kakali et al. 2001; Bich et al. 2009; Hafid and Hajjaji 2015). The band at $525 \mathrm{~cm}^{-1}$ indicates the vibration of $\mathrm{Si}-\mathrm{O}-\mathrm{Si}$ and $\mathrm{Si}-\mathrm{O}-\mathrm{Al}$ groups of the network (Kakali et al. 2001; Bich et al. 2009; Hafid and Hajjaji 2015). The crystalline phases found in K via XRD are shown in Fig. 2. The high quantity of iron oxide $(20.10 \%$ mass) is in accordance with the presence of lepidocrocite. The other minerals present are kaolinite, quartz and rutile. Calculation using X-ray diffraction along with chemical analysis (Bich 2005) enabled to get the quantitative mineralogical composition of $\mathrm{K}$ as shown in Additional file 3: Table S3.

\section{Waste glass}

Powder of V submitted to ICP-AES analysis led to the determination of its chemical composition which is given in Additional file 4: Table S4. The powder contains high amount of silica (68.70\% mass) and considerable quantity of $\mathrm{CaO}(14.30 \%$ mass) along with $\mathrm{Na}_{2} \mathrm{O}(12.60 \%$ mass) which enable to classify $\mathrm{V}$ as soda-lime glass (Djangang et al.

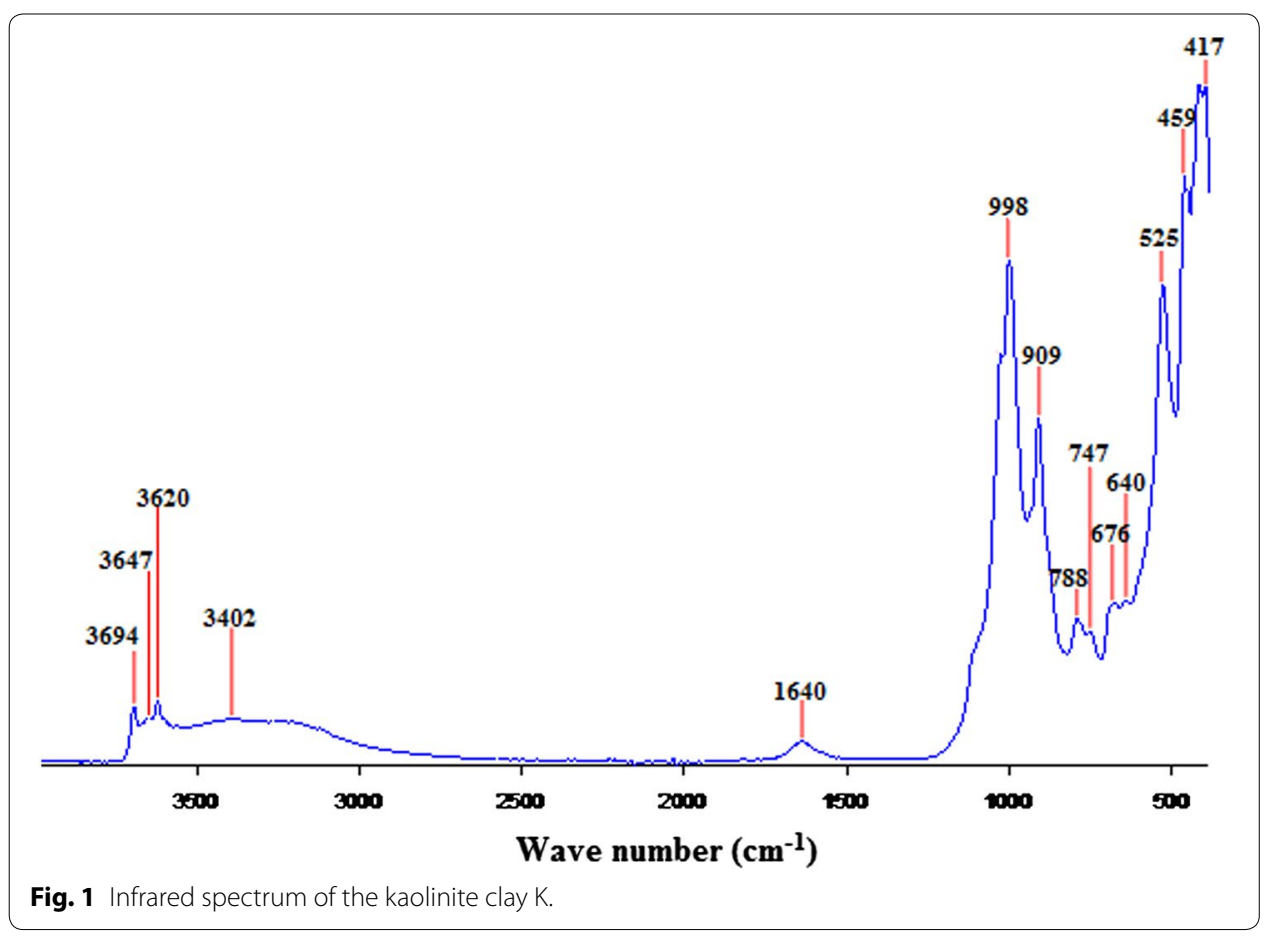




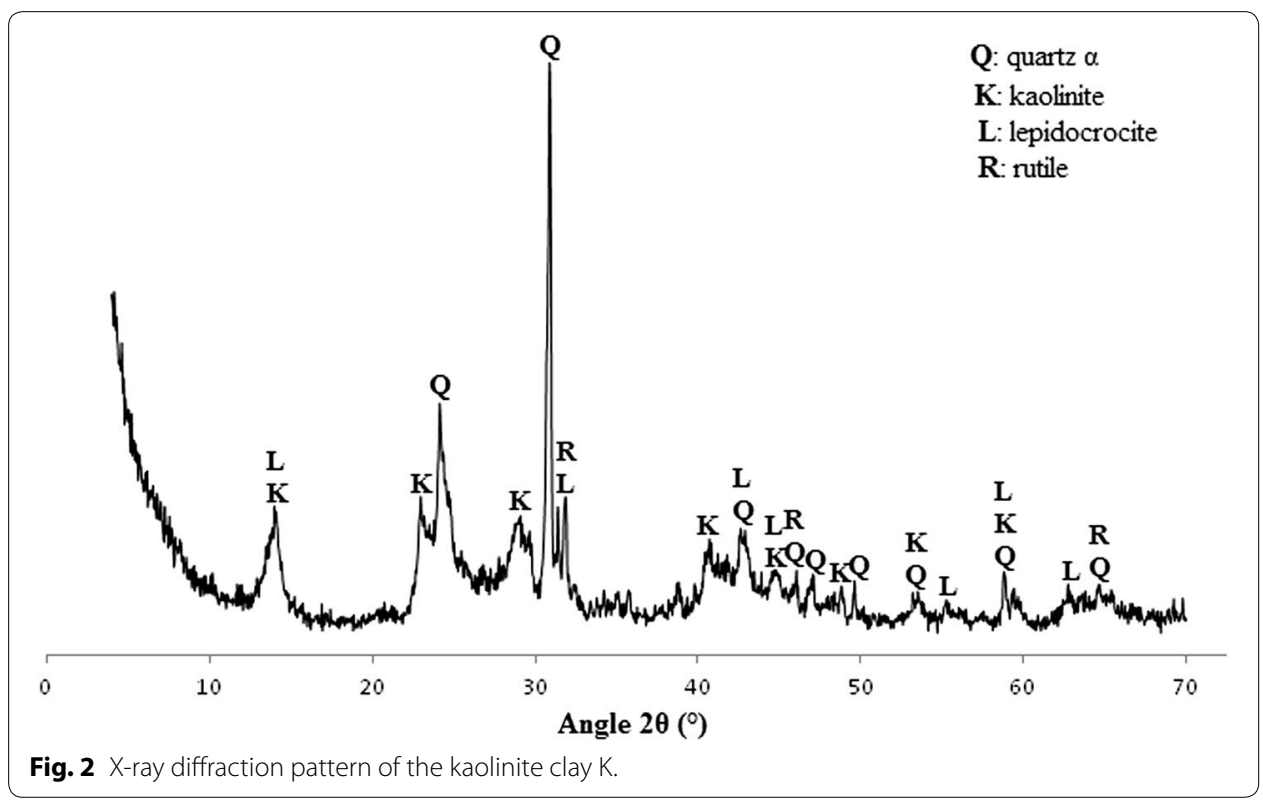

2014). Considerable amount of $\mathrm{Na}_{2} \mathrm{O}+\mathrm{K}_{2} \mathrm{O}(13.35 \%$ mass $)$ and $\mathrm{CaO}+\mathrm{MgO}(16.63 \%$ mass) could act as energetic fluxing agent when added with the $\mathrm{K}$ clay powder to get mixtures enabling to make terra cotta and associated products. Since V has little amount of colorizing oxides, mixing its powder with that of $\mathrm{K}$ clay will result in no significant change of color of fired products (Karaman et al. 2006; Djangang et al. 2007). Conversely, the presence of the above oxides in the mixtures will induce viscous flow phase to occur at relatively low temperature, since experimentally V melts around $700^{\circ} \mathrm{C}$. According to this, waste glass material can constitute a potential fluxing agent that can substitute feldspar for manufacturing ceramics. The main effect of utilizing waste glass here is then to reduce energy consumption with a view to achieve economic purpose. In addition, waste glass replaces completely feldspar since the latter is expensive and not available everywhere for effective economic consumption while the former is easily found free especially in certain urban zones (Raimondo et al. 2007; Andreola et al. 2008; Dondi et al. 2009). Figure 3 exhibits the FTIR spectrum of V. The bands respectively at 949 and $433 \mathrm{~cm}^{-1}$ are fingerprint of quartz (Bich et al. 2009; Tchakouté et al. 2013) while the one at $1,472 \mathrm{~cm}^{-1}$ expresses the vibration of $\mathrm{O}-\mathrm{C}-\mathrm{O}$ (Elimbi et al. 2011; Hafid and Hajjaji 2015) and this could be in accordance with the raw materials commonly used for the making of soda lime-glass. Also the band at $772 \mathrm{~cm}^{-1}$ expresses the absorption of quartz inferring mark of crystalline silica within the great amount of amorphous phase of the soda-lime V (Hafid and Hajjaji 2015). This is evidence of high amount content of silica as shown in the chemical composition of V (Additional file 4: Table S4). The XRD pattern of $\mathrm{V}$ is shown in Fig. 4 and exhibits mainly a large dome between $20^{\circ}$ and $40^{\circ}(2 \theta)$ which expresses great amorphous silica content (Park and Heo 2002) of V.

\section{Characterization of mixtures and ceramics}

Thermal behavior and color of the mixtures

Thermal analysis (DTA, TG and dilatometry) carried out on samples $\mathrm{KV}_{0}$ and $\mathrm{KV}_{2}$ are presented in Figs. 5, 6. For each sample, TG curve exhibits three loss of mass (Fig. 5). The 

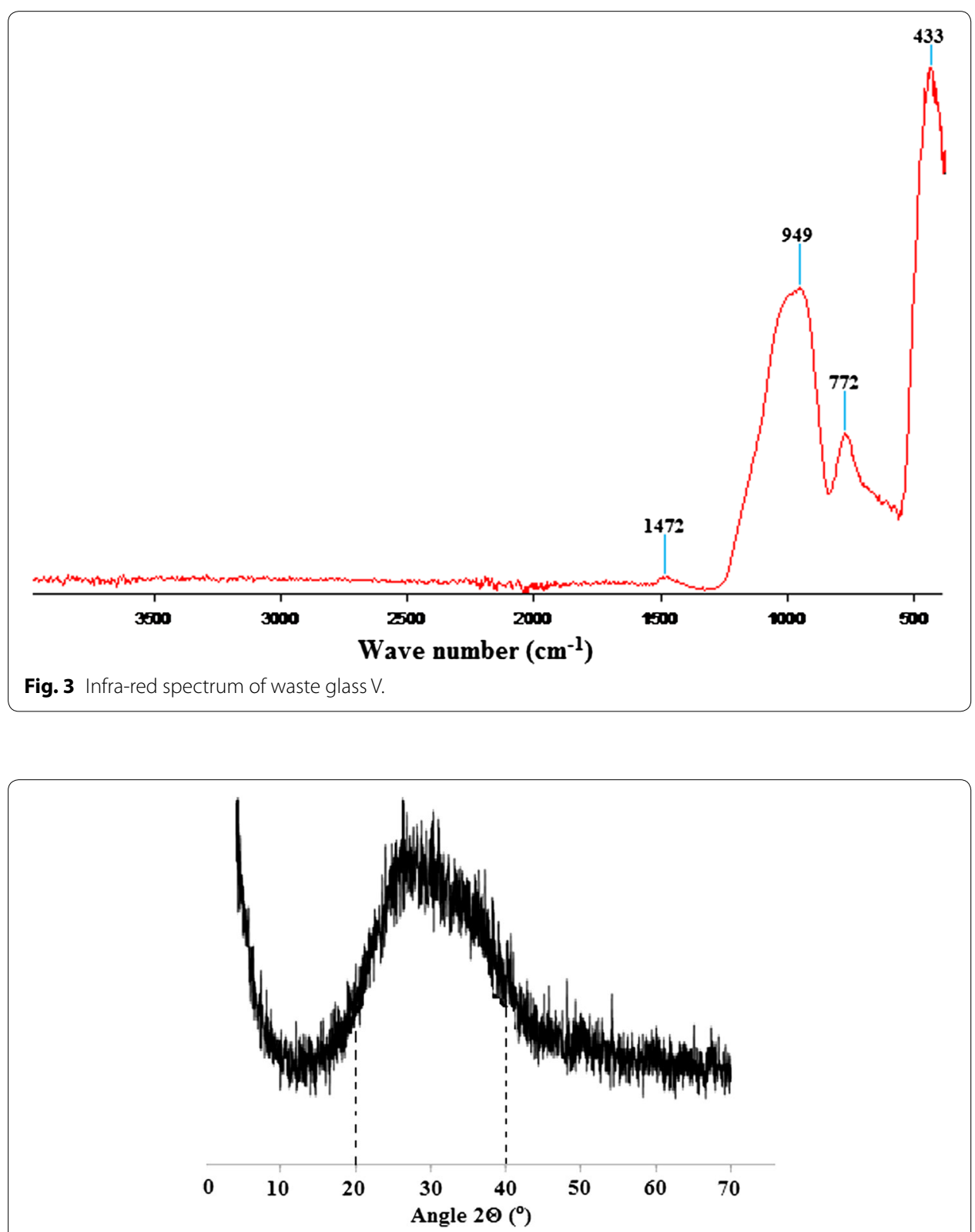

Fig. 4 X-ray diffraction pattern of waste glass $\mathrm{V}$.

first loss of mass corresponds to hydration water which is expressed by an endothermic peak around $100^{\circ} \mathrm{C}$ in DTA (Chakraborty 2003; Vieira et al. 2008; Phonphuak and Thiansem 2012). The second loss of mass is combination of exothermic and endothermic phenomena that extend between 150 and $400^{\circ} \mathrm{C}$. Thus, the exothermic dome with maximum around $200^{\circ} \mathrm{C}$ accounts for thermal decomposition of organic matter contained in the clay (Vieira et al. 2008). This exothermic reaction is followed by endothermic phenomenon around $300^{\circ} \mathrm{C}$ which is linked to deshydroxylation of lepidocrocite and it is well known that its transformation above $500^{\circ} \mathrm{C}$ leads to hematite (Rollet and Bouaziz 1972; Vieira et al. 2008). The last loss of mass accounts for dehydroxylation of kaolinite which is transformed into metakaolinite (Kakali et al. 2001; Bich et al. 2009; Hafid 


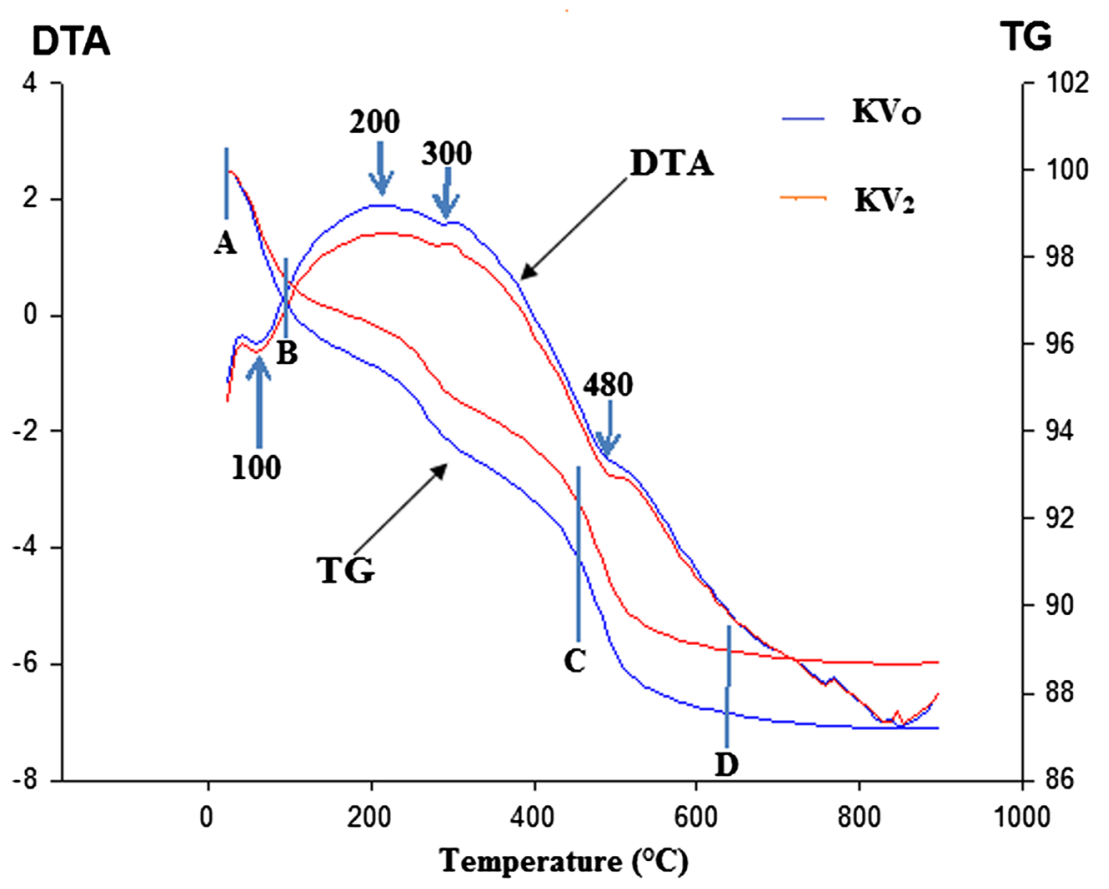

Fig. $5 \mathrm{TG} / \mathrm{DTA}$ curves of samples $K \mathrm{~V}_{0}$ and $K \mathrm{KV}_{2}$.

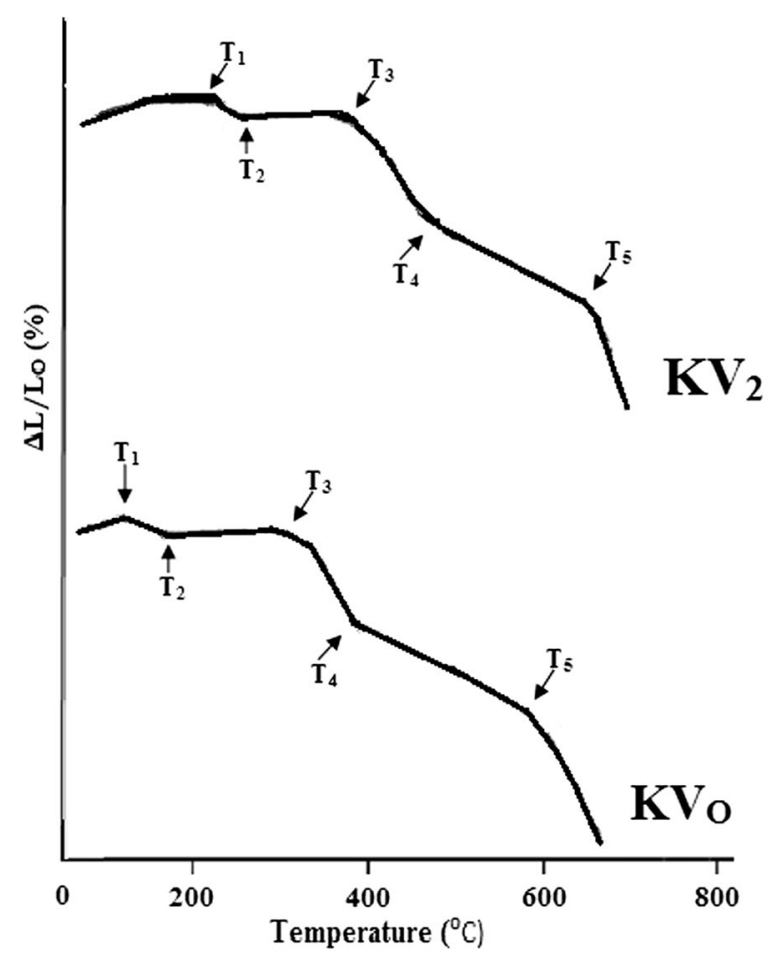

Fig. 6 Dilatometric curves of samples $\mathrm{KV}_{0}$ and $\mathrm{KV}_{2}$. 
and Hajjaji 2015). The dilatometric curves of $\mathrm{KV}_{0}$ and $\mathrm{KV}_{2}$ are shown in Fig. 6 and each exhibits five changes whose temperatures are summarized in Additional file 5: Table S5. According to Fig. 6 and Additional file 5: Table S5, $\mathrm{KV}_{0}$ exhibits lower temperature changes than $\mathrm{KV}_{2}$. This could result to the fact that up to $700^{\circ} \mathrm{C}$, the waste glass does not melt but behaves as filler in the mixtures. As a result of this, temperature $\mathrm{T}_{1}$ (elimination of hydration water) and $\mathrm{T}_{2}$ and $\mathrm{T}_{3}$ which may be in relation with the dehydroxylation of lepidocrocite are smaller for $\mathrm{KV}_{0}$ than their counterpart of $\mathrm{KV}_{2}$. This filler behavior of waste glass is also encountered for temperatures $T_{4}$ and $T_{5}$ which are in relation with dehydroxylation of kaolinite. When unfired, all samples are reddish yellow (Additional file 6: Table S6 and Fig. 7). Fired samples are red (Additional file 6: Table S6 and Fig. 7) and this correlates well with the existence of hematite in presence of rutile in the fired samples (Fig. 8). Thus, addition of $10 \%$ mass or more of waste glass with K clay does not hinder to get red colored ceramics destined for the making of fired bricks or roofing tiles.

\section{$X R D$ and FTIR analysis}

Figure 8 presents the $X$-ray patterns of fired products of samples $K V_{0}$ and $K V_{2}$ which provide the mineralogical phases such as quartz $\alpha$, rutile and hematite. This last crystalline phase is probably a neomineral resulting from thermal deshydroxylation of lepidocrocite (Rollet and Bouaziz 1972; Vieira et al. 2008). Both rutile and hematite are the main minerals enabling to obtain red ceramics (Karaman et al. 2006; Vieira et al. 2008). Quartz is the mineral initially present in the $\mathrm{K}$ clay and the intensities of its main peaks (3.34 and $4.27 \AA$ ) are lower for $\mathrm{KV}_{2}$ than for $\mathrm{KV}_{0}$ because the incorporation of powder glass (amorphous material) in the clay diminishes its amount of sand and silt. Also, there is total transformation of kaolinite at $750^{\circ} \mathrm{C}$ (Elimbi et al. 2011) and this may expect to generate low swelling ceramics when put in contact with liquids such as water, hence to allow more sustainability. The absence of kaolinite in the fired products is also confirmed by FTIR spectra (Fig. 9). In fact in the fired products, the absorption band at $3,694-3,620 \mathrm{~cm}^{-1}$ which expresses the stretching vibrations of $-\mathrm{OH}$ groups of kaolinite network (Elimbi et al. 2011) (Fig. 1) is absent (Fig. 9). Also, except for the decreasing

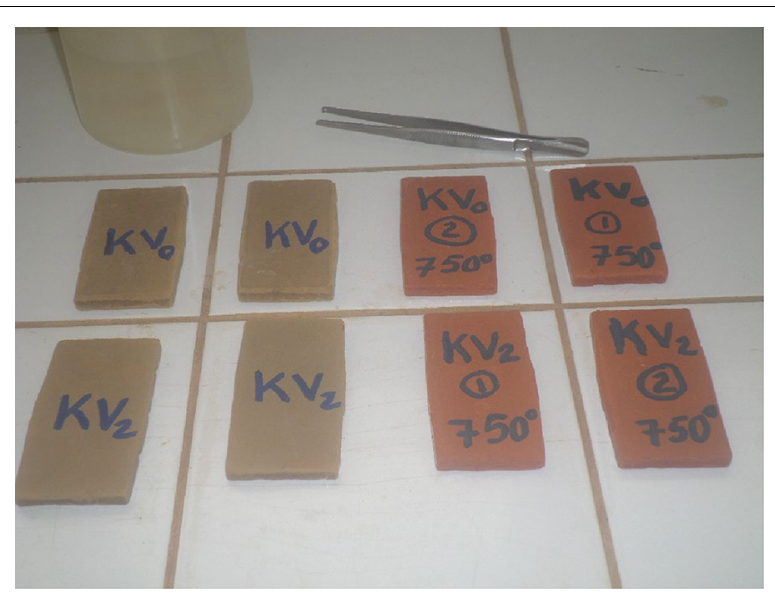

Fig. 7 Visual aspect of unfired (left) and fired (right) samples of $\mathrm{KV}_{0}$ and $\mathrm{KV}_{2}$. 
of quartz peaks, the aspects of X-ray patterns or FTIR spectra of fired products do not change significantly when mixing up to $10 \%$ of waste glass powder with the K clay (Figs. 8, 9).
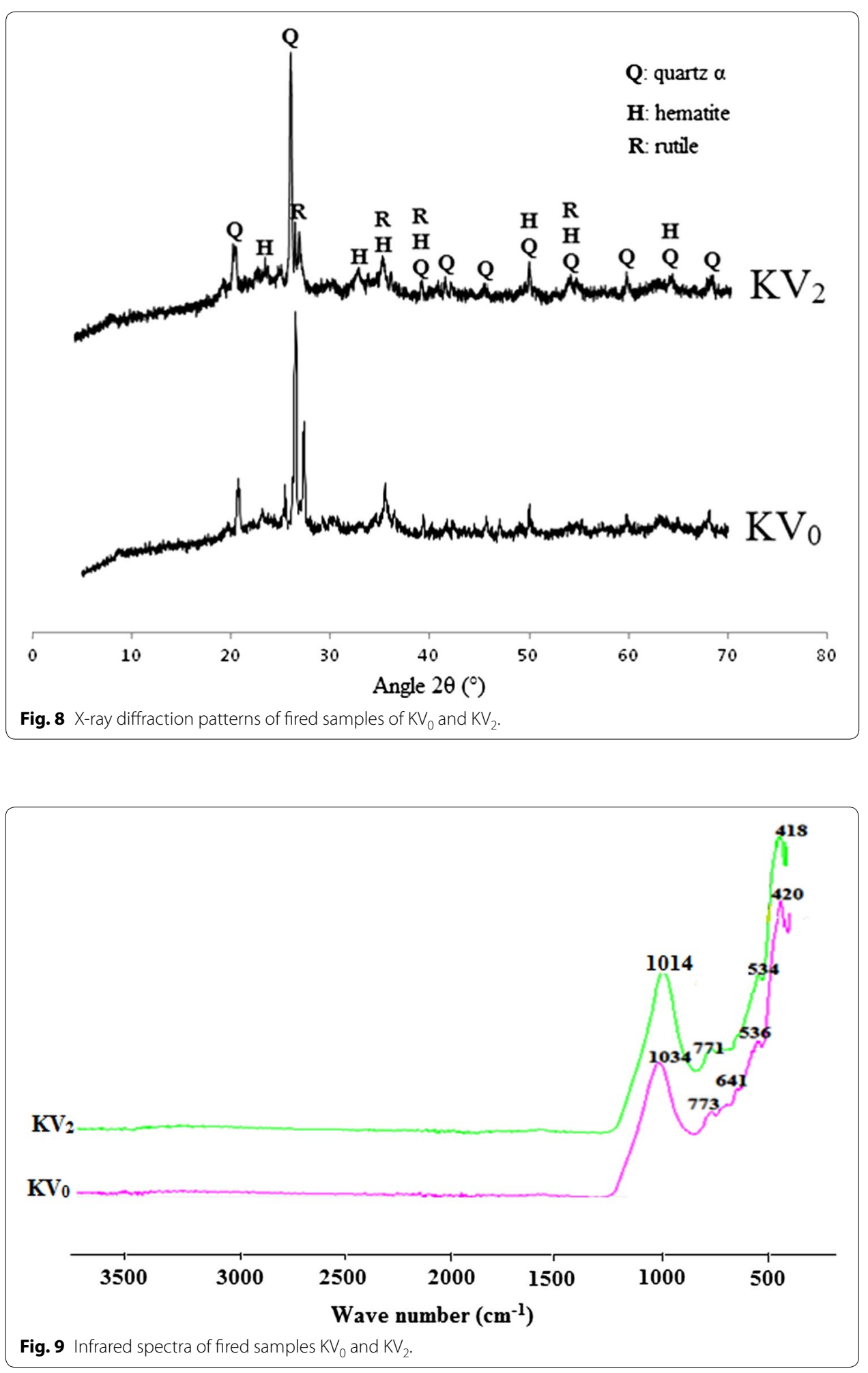


\section{Physical and mechanical properties}

Linear shrinkage and water absorption and flexural strength of samples initially fired at $750^{\circ} \mathrm{C}$ are shown in Fig. 10. Addition of waste glass up to $15 \%$ mass leads to increase linear shrinkage from 0.70 to $1.20 \%$. This increase correlates with the chemical transformations which take place during the heating of the samples. Among these are elimination of structural water of kaolinite, formation of new crystalline phase (hematite), dissolution

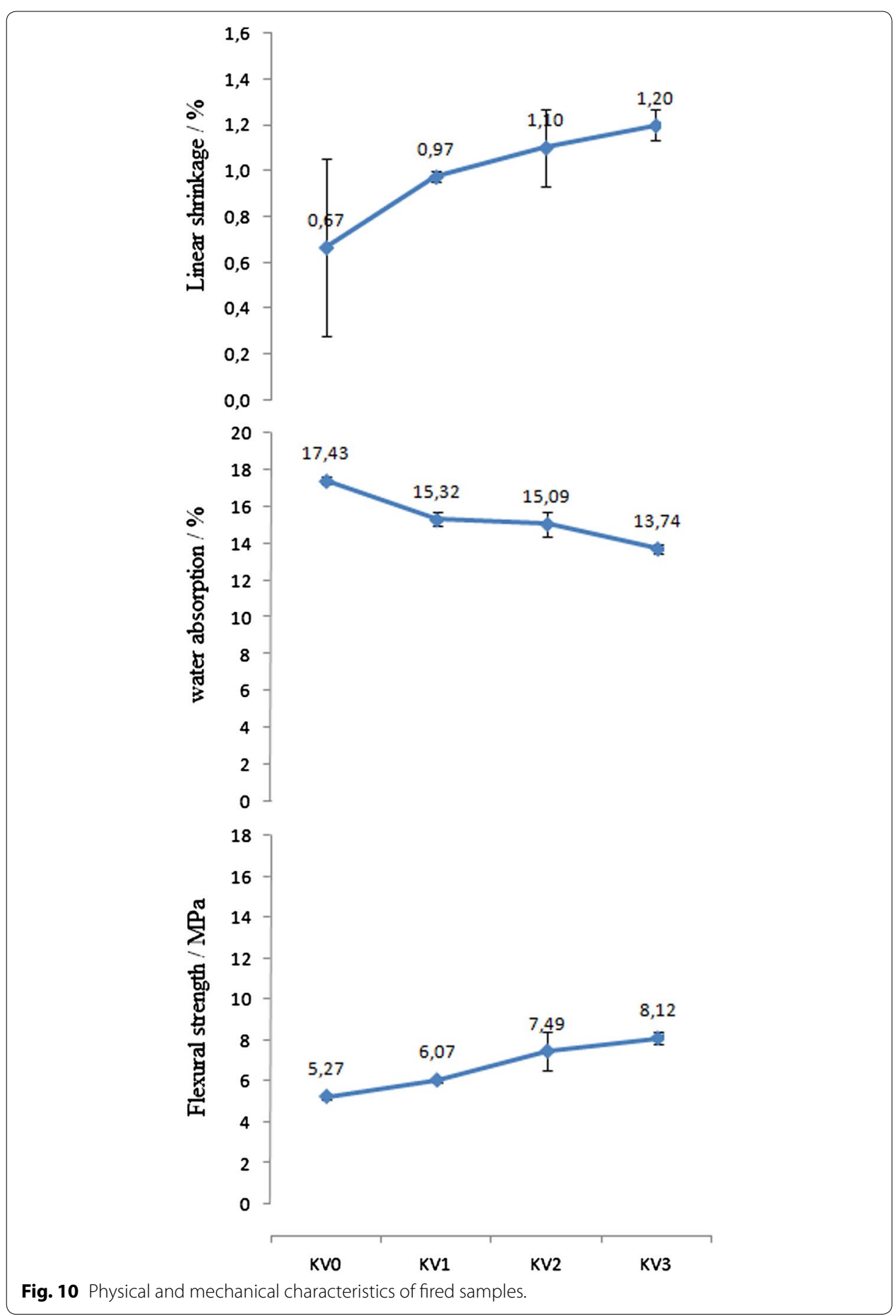


of quartz via the vitreous phase generated by the fusion of waste glass (Fig. 8). Anyhow, increase of linear shrinkage of fired products is an expression of their reactivity and this is emphasized when the additive (V) increases up to $15 \%$ mass. The water absorption percentage decreases from 17.40 to 13.70 when the mass percentage of $\mathrm{V}$ increases up to 15 (Fig. 10). This behavior is attributed to the vitreous phase brought about by waste glass. In fact the amount of this vitreous phase increases with increase of waste glass percentage and gradually, this viscous phase wraps up particles of the samples. Hence progressive decrease of voids within the samples leads to the decrease of water absorption percentage (Vieira et al. 2008; Phonphuak and Thiansem 2012; Pérez-Villarejo et al. 2015; Sultana et al. 2015). Flexural strength is a characteristic which is strongly dependent of voids: the lower there are voids, the higher are the values of flexural strength of fired products. As the mass percentage of $\mathrm{V}$ increases up to $15 \%$, there is a noticeable tendency of increase of flexural strength of fired samples between 5.30 and $8.10 \mathrm{MPa}$. As previously mentioned, these results are in accordance with the variation of water absorption as consequence of viscous flow mechanism, inducing densification through consolidation of particles of fired samples. Vitrification then causes the reduction of porosity and therefore samples experience increase of mechanical strength (Chen et al. 2011; Emrullahoglu 2014; Bernhardt et al. 2014; Hafid and Hajjaji 2015). Thus, with respect to above mentioned, this process can be technologically applied for the production of fired bricks, roofing tiles, rustic floor or wall tiles and related materials which could be used for masonry purpose and sustainable development.

\section{Conclusion}

Red ceramics were produced by heating $\left(750^{\circ} \mathrm{C}\right)$ samples of mixtures of reddish yellow colored kaolinite clay with waste glass (percentage ranging between 0 and $15 \%$ mass). The chemical analysis of the clay revealed both low content of alkaline oxides and rich amount of ferrous oxide. The mineralogical characterization of the clay revealed the presence of minerals such as kaolinite, quartz $\alpha$, rutile, lepidocrocite and others unconfirmed phases attributed particularly to organic matter as confirmed by thermal analysis. Waste glass can be considered as potential fluxing additive that can substitute feldspars in terra cotta for low heating temperature production. Hence increasing the mass percentage of waste glass in mixtures with kaolinite clay leads to fired products whose linear shrinkage and flexural strength increase while there is decrease of water absorption. This is attributed to the densification of samples via the viscous flow mechanism induced by a vitreous phase brought about by the fusion of waste glass. The obtained results show that mixing waste glass with poorly alkaline oxide and abundant ferrous oxide kaolinite clay content is an interesting process to get red ceramics destined for the making of bricks or roofing tiles at $750^{\circ} \mathrm{C}$.

\section{Additional files}

Additional file 1: Table S1. Composition of the mixtures of $K$ and $V$ expressed as mass percentage Additional file 2: Table S2. Chemical compositions of the kaolinite clay K (LOI = Loss On Ignition). Additional file 3: Table S3. Mineralogical composition of the kaolinite clay $\mathrm{K}$.

Additional file 4: Table S4. Chemical composition of waste glass V (LOI = Loss On Ignition).

Additional file 5: Table S5. Temperature changes on the dilatometry curves of $\mathrm{KV}_{0}$ and $\mathrm{KV}_{2}$. Additional file 6: Table S6. Variation of color of samples with firing temperature. 


\section{Abbreviations}

DTA: differential thermal analysis; EN: European norm; FTIR: fourier transform infrared spectroscopy; ICP-AES: inductive coupled plasma-atomic emission spectrometry; K: kaolinite clay; KV: mixture of Kaolinite clay and glass powder; NF: Norme Française; S.G.D.G: Sans Garantie Du Gouvernement; TG: thermogravimetry; V: glass powder; XRD: X-ray diffraction.

\section{Authors' contributions}

ET and AE participated in the research process. JDM helped for the determination of different crystalline phases on the DRX patterns and for grinding and sieving the raw materials (both clay and waste glass). ABT helped to collect the raw materials and to achieve thermal analysis. All authors read and approved the final manuscript.

\section{Author details}

${ }^{1}$ Laboratoire de Chimie Minérale Appliquée, Faculté des sciences, Université de Yaoundé 1, B.P. 812, Yaoundé, Cameroon. ${ }^{2}$ Laboratoire de Chimie Analytique, Faculté des Sciences, Université de Douala, B.P. 24157, Douala, Cameroon. ${ }^{3}$ Laboratory of Materials, Local Materials Promotion Authority, PO Box 2396, Yaoundé, Cameroon.

\section{Compliance with ethical guidelines}

\section{Competing interests}

The authors declare that they have no competing interests.

Received: 18 May 2015 Accepted: 28 July 2015

Published online: 25 August 2015

\section{References}

Aliprandi G (ed) (1979) Matériaux réfractaires et céramiques techniques. Septima, Paris

Andreola F, Barbieri L, Karamanova E, Lancellotti I, Pelino M (2008) Recycling of CRT panel glass as fluxing agent in the porcelain stoneware tile production. Ceram Int 34:1289-1295

Arib A, Sarhiri A, Moussa R, Remmal T, Gomina M (2007) Caractéristiques structurales et mécaniques de céramiques à base d'argiles: influence de la source de feldspath. C R Chimie 10:502-510

Aubert JE, Fabbri A, Morel JC, Maillard P (2013) An earth block with compressive strength higher than 45 MPa! Constr Build Mater 47:366-369

Bernhardt M, Justnes H, Tellesbo H, Wiik K (2014) The effect of additives on the properties of lightweight aggregates produced from clay. Cem Concr Compos 53:233-238

Bich C (2005) Contribution à l'activation thermique du kaolin: évolution de la structure cristallographique et activité pouzzolanique. Ph.D Thesis, Institut National des Sciences Appliquées de Lyon

Bich C, Ambroise J, Péra J (2009) Influence of degree of dehydroxylation on the pozzolanic activity of metakaolin. Appl Clay Sci 44:194-200

Bragança S, Bergmann C (2004) Traditional and glass powder porcelain: technical and microstructure analysis. J Eur Ceram Soc 24:2383-2388

Chakraborty AK (2003) DTA study of preheated kaolinite in the mullite formation region. Therm Acta 398:203-209

Chen Y, Zhang Y, Chen T, Zhao Y, Bao S (2011) Preparation of eco-friendly construction bricks from hematite tailings. Constr Build Mater 25:2107-2111

Djangang NC, Elimbi A, Melo CU, Nkoumbou C, Lecomte G, Yvon J et al (2007) Characteristics and ceramic properties of clays from Mayoum deposit (West Cameroon). Ind Ceram 27(2):79-88

Djangang NC, Kamseu E, Elimbi A, Lecomte G, Blanchart P (2014) Net-shape clay ceramics with glass waste additive. Mater Sci Appl 5:592-602

Dondi M, Guarini G, Raimondo M, Zanelli C (2009) Recycling PC and TV waste glass in clay bricks and roof tiles. Waste Manag 29:1945-1951

Elimbi A, Tchakouté HK, Njopwouo D (2011) Effects of calcination temperature of kaolinite clays on the properties of geopolymer cements. Constr Build Mater 25:2805-2812

Elimbi A, Dika MJ, Djangang NC (2014) Effects of alkaline additives on the thermal behavior and properties of cameroonian poorly fluxing clay ceramics. J Miner Mater Char Eng 2:484-501

Emrullahoglu ACB (2014) Effect of borogypsum on brick properties. Constr Build Mater 59:195-203

Ergul S, Akyildiz M, Karamanov A (2007) Ceramic material from basaltic tuffs. Ind Ceram 27(2):89-94

Ganwa AA, Wolfang F, Wolfgang S, Cosmas KS, Mvondo Ondoa J, Muharrem S et al (2008) Zircon ${ }^{207} \mathrm{~Pb} / 206 \mathrm{~Pb}$ evaporation of PanAfrican metasedimentary in the Kombé II area (Bafia Group, Cameroon). J Afr Earth Sci 51:77-88

Hafid KE, Hajjaji M (2015) Effects of the experimental factors on the microstructure and the properties of cured alkaliactivated heated clay. Appl Clay Sci. doi:10.1016/j.clay.2015.03.015

Kakali G, Perraki T, Tsivilis S, Badogiannis E (2001) Thermal treatment of kaolin: the effect of mineralogy on the pozzolanic activity. Appl Clay Sci 20:73-80

Karaman S, Gunal H, Ersahin S (2006) Assessment of clay bricks compressive strength using quantitative values of colour components. Constr Build Mater 20:348-354

Munsell Soil Color Charts (ed) (2000) Washable. Maryland, USA

Norme Européenne EN-100 (eds) (1982) Détermination de la résistance à la flexion

Norme Française NF-P-18-554 (eds) (1979) Mesures des masses volumiques, porosité, coefficient d'absorption d'eau et en teneur en eau des gravillons et cailloux, France

Nzenti JP, Njanko T, Njiosseu ELT, Tchoua FM (1998) Les domaines granulitiques de la chaine Panafricaine Nord-Equatoriale au Cameroun. Vicat JP et Bilong P, collection GEOCAM, Presse Univ Yaoundé 
Oti JE, Kinuthia JM (2012) Stabilised unfired clay bricks for environmental and sustainable use. Appl Clay Sci 58:52-59

Park YJ, Heo J (2002) Conversion to glass-ceramics from glasses made by MSW incinerator fly ash for recycling. Ceram Int 28:689-694

Pérez-Villarejo L, Martínez-Martínez S, Carrasco-Hurtado B, Eliche-Quesada D, Ureña-Nieto C, Sánchez-Soto PJ (2015) Valorization and inertization of galvanic sludge waste in clay bricks. Appl Clay Sci 105-106:89-99

Phonphuak N, Thiansem S (2012) Using charcoal to increase properties and durability of fired test briquettes. Constr Build Mater 29:612-618

Quijorna N, Coz A, Andres A, Cheeseman C (2012) Recycling of Waelz slag and waste foundry sand in red clay bricks Resour Conserv Recycl 65:1-10

Raimondo M, Zanelli C, Matteucci F, Guarini G, Dondi M, Labrincha JA (2007) Effect of waste glass (TV/PC cathodic tube and screen) on technological properties and sintering behaviour of porcelain stoneware tiles. Ceram Int 33:615-623

Rambaldi E, Carty WM, Tucci A, Esposito L (2007) Using waste glass as a partial flux substitution and pyroplastic deformation of a porcelain stoneware tile body. Ceram Int 33:727-733

Rollet A, Bouaziz R (eds) (1972) L'analyse thermique, Tome 2, L'examen des processus chimiques. Gauthier-Villars, 55, quai des Grands-Augustins, Paris $6^{\mathrm{e}}$

Rozenstrauha J, Bajare D, Cimdins R, Berzina L, Bossert J, Boccaccini AR (2006) The influence of various additions on a glass-ceramic matrix composition based on industrial waste. Ceram Int 32:115-119

Sei J, Abba TA, Olivier-Fourcade J, Quiquampoix H, Staunton S, Jumas JC, Womes M (2004) Characterisation of kaolinitic clays from the Ivory Coast (West Africa). Appl Clay Sci 27:235-239

Sultana MS, Ahmed AN, Zaman MN, Rahman MA, Biswas PK, Nandy PK (2015) Utilization of hard rock dust with red clay to produce roof tiles. J Asian Ceram Soc 3:22-26

Suzuki S, Tanaka M (1997) Glass-ceramic from sewage sludge ash. J Mater Sci 32:1775-1779

Tchakouté KH, Elimbi A, Yanne E, Djangang NC (2013) Utilization of volcanic ashes for the production of geopolymers cured at ambient temperature. Cem Concr Compos 38:75-81

Traoré K, Blanchart P, Jernot JP, Gomina M (2007) Caractérisation physicochimique et mécanique de matériaux céramiques obtenus à partir d'une argile kaolinitique du Burkina Faso. C R Chimie 10:511-517

Vieira CMF, Sanchez R, Monteiro SN (2008) Characteristics of clays and properties of building ceramics in the state of Rio de Janeiro, Brazil. Constr Build Mater 22:781-787

Yakoubi NE, Aberkan M, Ouadia M (2006) Potentialité d'utilisation d'argiles marocaines de Jbel Kharrou dans l'industrie céramique. C R Geosci 338:693-702

Zhang L (2013) Production of bricks from waste materials—a review. Constr Build Mater 47:643-655

\section{Submit your manuscript to a SpringerOpen ${ }^{\circ}$ journal and benefit from:}

- Convenient online submission

- Rigorous peer review

- Immediate publication on acceptance

- Open access: articles freely available online

- High visibility within the field

- Retaining the copyright to your article

Submit your next manuscript at $\boldsymbol{s p r i n g e r o p e n . c o m ~}$ 